\title{
Rediscovering Chinese narrative tradition: an introduction
}

\author{
Péter Hajdu ${ }^{1,2}$
}

Published online: 19 March 2018

(C) Akadémiai Kiadó, Budapest, Hungary 2018

Narratology tends-or at least used to tend-to claim universal validity. If it provides a theoretical toolbox with which all the narratives produced by mankind can be described and categorised, there is no need for local, national, areal, or historical versions of narrative theory, though this does not imply that one should deny the existence of local, national, areal, or historical narrative traditions. However, narrative theory does not evolve in a vacuum; its purpose has never been to elaborate a purely theoretical system that can be adapted to every possible narrative, be they long forgotten narratives of the past or ones that are to develop in the future. Narratology is supposed to describe real(ly existing) narratives, and it has always been driven and inspired by the analysis of real narratives, well known by the analysers, obviously. Real narratives necessarily belong to some particular traditions, and therefore some particular traditions have to have an impact on narrative theory. Skaz may be a case in point since it is a notion that is defined in every lexicon of narratology in any language. As a Russian or Eastern-European oral folklore genre of narrative, however, skaz became a key term of Russian formalist stylistics to mean any "literary style imitating oral monologue." 1 Once used as an abstract concept of literary criticism, it was adaptable to literary phenomena outside the Russian or East-European tradition. It can thus be argued that Ring Lardner's "Haircut" or Mark Twain's Huckleberry Finn, ${ }^{2}$ as well as the "Cyclops" episode of James Joyce's Ulysses, William Faulkner's first version of Spotted Horses, and J.D. Salinger's Catcher in the Rye are also examples of

\footnotetext{
1 Banfield (2005, p. 693), cf. Eikhenbaum (1962).

2 Prince (1987, p. 88).

$\triangle$ Péter Hajdu pethajdu@gmail.com

1 Shanghai Jiao Tong University, Shanghai, China

2 Research Centre for the Humanities, Hungarian Academy of Sciences, Budapest, Hungary
} 
skaz. ${ }^{3}$ The study of Russian folklore narrative forms resulted in general insights about the possibilities of a special kind of narrative that can be applied to British and American $^{4}$ works of highbrow literature.

The example of skaz, however, seems uncharacteristic from the viewpoint of adaptation. It is rarer-although not exceptional - that notions developed from the analysis of one of the literatures Franco Moretti described as peripheral are adapted to those that he calls core literatures. ${ }^{5}$ We can find innumerably more examples of adaptation the other way around. Moretti spoke about European literature mostly, and said nothing about premodern non-European literary development, which obviously had its own core areas. But with the European global hegemony during the period of colonization and then globalisation, the previous cores have become just other peripheries. It is well known that Earl Miner saw major gaps between literary systems and realised that importing western notions can only seemingly bridge them. ${ }^{6}$ The problems of travelling theories are also widely discussed. ${ }^{7}$ Although the situation created by adapting concepts of core literary studies to the phenomena of the peripheries is unsatisfactory and may also seem unfair, it is still better than the other possibility, namely that local traditions be analysed exclusively on their own terms. Such a practice would result in isolation and an inability to dialogue.

About a decade ago a sort of movement started in China to develop a Chinese narratology as a rebellion against the dominance of invasive Western theories. ${ }^{8}$ Let us imagine for a moment the complete success of such a movement! All the Chinese narratives would be analysed with a Chinese theoretical toolkit and through notions excavated from the Chinese intellectual tradition. Such an isolated discourse could not communicate with the outside world, which would be a loss to everyone. Only Sinologists specialised in that particular narratology could have even a vague idea of the characteristics of Chinese narrative traditions, while others would necessarily have the impression that the Chinese tradition is so basically different that it offers no access at all, and therefore cannot offer anything worth the effort, since, according to Schleiermacher, what is not even partially familiar cannot be understood. ${ }^{9}$

\footnotetext{
3 Banfield (2005, p. 693).

${ }^{4}$ Banfield also mentions the Yiddish stories of Sholem Aleichem, but I do not discuss them separately since they were mostly written in Russian context, at least geographically and historically speaking. It is probably the Yiddish tradition that makes scholars of skaz describe it rather as an East-European than a Russian form, although Endre Bojtár in his short entry of skaz in the nineteen volume Hungarian dictionary of general literature [a literal translation would be world literature, but see Gillespie (2016, p. 48)] mentions the Polish goweda as its equivalent (Bojtár 1992, p. 493). This argument of mine may be weakened by Bojtár's mentioning another equivalent, medieval French dit, less convincingly, I think.

5 Namely English and French: Moretti (1999, 2000).

6 Miner (1990).

7 I am obliged to refer to Edward Said's much quoted paper (Said 1982), but what I have in mind is rather its reception; Said analysed the travel of a theory from the periphery to the core, while many after him were concerned of the imperial bias of theories travelling to the peripheries.

${ }^{8}$ Qiao (2015, pp. 639-640).

9 “...und freilich, wenn das zu Verstehende dem, der verstehen soll, ganz fremd wäre und es gar kein beiden Gemeinschaftsliches gäbe: so gäbe es auch keinen Anknüpfungspunktfür das verstehen." "...wenn alles schlechthin fremd wäre, die Hermeneutik ihr Werk gar nicht anzuknüpfen wüßte." (Schleiermacher 1977, pp. 313-314.)
} 
It does not need much argumentation to see that most of the basic notions of narratology (like e.g. character, plot, scene etc.) can be easily adapted in any narrative tradition. When in some narrative traditions we find phenomena that cannot be satisfactorily described with the current theoretical toolkit, then we see, on the one hand, the uniqueness of those traditions, and on the other, the need to further elaborate the system of narrative theory-maybe by enriching it with new notions imported from the local scholarly tradition that has tried to cope with those phenomena in the past. If some of our general ideas (which we would like to regard as universal) do not work for a (local, national, areal, or historical) kind of narrative, that again tells us something about both the given kind of narrative and the supposedly universal ideas.

Contributors to the mini-cluster on "Rediscovering Chinese narrative traditions" convened by Biwu Shang read the Chinese narrative tradition from the dual perspective of current Western theories and former Chinese philology, which reveals some peculiarities of the analysed Chinese material and may help to refine the theories applied. This dialectics is most visible in Yuzhen Lin's paper "Fictionality as a rhetorical resource in Zuozhuan," which tests the usability of the rhetorical theory of fictionality first proposed by Richard Walsh ${ }^{10}$ in understanding the strategies of presentation in a highly important source of ancient Chinese history. According to her this source, which probably goes back to the fifth century $\mathrm{BCE}$, is the first Chinese work that can be rightly called historiography. She also bases her analysis on the philological achievements of generations of Chinese scholars discussing that intriguing text. Lin uses Xiuyan Fu's description of the five types of "mysterious events" in Zuozhuan, ${ }^{11}$ and then takes the rhetorical theory of fictionality (as formulised in a collaborative paper from the 2015 issue of Narrative $^{12}$ to prove that they can rightly be called the fictional elements of the narrative, which are also innovative additions to the former tradition of Chinese historiography. Rhetorical theory of fictionality proves to be a useful approach to ancient Chinese historiography, while the paper highlights the importance of a historical perspective for that theory.

If fictionality is a rhetorical device that can be applied to perform a function in a given communicative situation, written communication must have some peculiar features, especially a written communication in which the time of writing and the time of reading are ages apart. Lin regards as fictional all cases of communication between human and divine spheres and apparent divine interventions in the human world ("divinations, omens, apparitions, acts of mysterious justice, and dream [revealing the future]"). If we imagine a reader contemporary to the composition of Zuozhuan, we have to conclude that in his or her communication with the text these features were not fictional. For the present-day reader, educated in a secular society, such stories cannot be accepted as factual reports. A text can change its factual/fictional status due to changes in the context of communication.

\footnotetext{
${ }^{10}$ Walsh (2007).

11 Fu (1999, pp. 202-207).

12 Nielsen et al. (2015).
} 
For me as a western reader who is more familiar with the development of European historiography, it is particularly interesting that in China stories of divine intervention appeared in a later phase of historical records as (fictional) embellishments. In Rome the earliest annual records (the annales) already contained the prodigies of the current year and natural catastrophes (also regarded as omens) as "events of public concern" along with the names of the magistrates, treaties or declarations of war. ${ }^{13}$ This tells something about the attitude of the respective educated classes, which had a monopoly on the production of writing. While the Roman elite functioned as a communication interface between humans and the gods, ${ }^{14}$ and therefore were highly interested in omens, premonitions and prodigies, the Chinese elite, it seems, mostly appreciated truth, i.e. facts that can be checked. This impression is only seemingly contradicted by the overwhelming presence of the supernatural in the Chinese narrative tradition (in comparison to western one), since what we would call fiction in the earlier Chinese context was in fact accurate records of the stories and attitudes of the uneducated, superstitious masses, information which could be useful for the governing elite. ${ }^{15}$

Biwu Shang uses unnatural narratology to see the peculiarities of Zhiguai tales. Unnatural narratology is not a unified (sub)discipline, since its proponents have different ideas about what makes a narrative unnatural and how to cope with unnatural narrative or unnatural elements of narratives. What seems to connect unnatural narratologists is their resoluteness to intentionally face up to the unnatural and to refuse interpretive practices that "tame" the strangeness of a narrative in one way or another, to explain why the seemingly unnatural features are actually natural. Shang is closest to Jan Alber's concept of the unnatural narrative, namely that impossible elements make a narrative unnatural, ${ }^{16}$ and a narrative that contains impossible elements is thus unnatural. The impossibility of things should be measured by today's science-based common sense. It is small wonder that Shang finds many impossible or unnatural elements in a genre that he agrees with Xiofei Tian to define as an eastern parallel to paradoxography, "writings about marvels." 17 The paper offers a typology of the unnatural in those marvel stories. As he convincingly argues, one can put a finger on the unnatural both on the local level in single impossible elements of the story world, and on the global level of the narrative in the characters' crossing theoretically impenetrable boundaries of separate spheres of existence. The unnatural elements can be non-human characters, impossible time and impossible space. The impossible boundary-crossings can include returning from the world of the dead, or commuting between the spheres of spirits and humans or animals and humans.

Narrative studies tend to take it for granted that a narrative (obviously told by and to human beings) is about the human existence, and therefore that characters of a narrative should be humans. Of course there are so many narratives in which the

\footnotetext{
${ }^{13}$ Conte (1999, pp. 17, 178-191)

14 Rosenberger (2007, p. 296).

15 Rajkai (2003, pp. 178-181).

16 Alber (2016, pp. 1-7).

17 Tian (2010, p. 202).
} 
characters are not that a loophole is usually provided, namely that the characters are human or human-like. Jan Alber's unnatural narratology, which focuses on recent and contemporary literature, challenges this view through analysing characters like robots, cyborgs or genetically engineered partially human half-breeds. ${ }^{18}$ Shang tries to support this counter-argument against the presupposition of anthropomorphic characters through showing non-human characters in old Chinese tales, like ghosts, animals, material objects, and fairies.

The problem with Shang's argument, I fear, is that all of his examples of nonhuman characters are very human-like. If a female ghost marries a human being, bears children to him and even raises them, it is difficult to argue that this is not a human-like ghost. In all the examples collected in the paper, the non-human characters have emotions and ambitions rather characteristic of human beings. In many cases they have a human appearance too, so the human characters cannot tell (sometimes for decades) that they are not actually human. In "The brindled fox at the ancient tomb" a fox in human guise discusses history, literature and philosophy, and what makes the human protagonist suspicious about its human nature is its overwhelming knowledge of the humanities. The fox knows so much-in human terms - that it cannot be human. Still I think that collecting this material is useful because it highlights a central feature of unnatural narratology, namely that the unnatural depends on focus and interpretation. The nonhuman characters have many human traits, and a narrative analysis that is not interested in finding and facing the unnatural can easily disregard the non-human traits, while focusing on the latter may make the whole narrative unnatural.

As a western reader I also find this material to be a good basis for comparison, and I would like to formulate some tentative ideas for future analyses. (1) Although the non-human characters of Chinese stories are rather human-like, a different kind of anthropomorphism seems to work here from the western tradition. A speaking animal is an allegory of a human being. The speaking wolf in Phaedrus' fable is the allegory of an aggressive, unjust, powerful man, while the lamb is the allegory of the innocent. A fox that takes the form of a man and discusses philosophical dilemmas, or takes the form of a woman and spends years happily married to a man, cannot be interpreted allegorically. Animals are also regarded as more powerful than humans in a totem culture-and the idea is based on the primary experience that animals are stronger, faster and have more developed senses than humans; but here the animals have superpowers and they are better even in things that only humans do. (2) The idea that a creature can behave as a human but be an animal, a ghost, a fairy etc. in reality - a reality hardly accessible to human beings - can be connected to the absence in eastern cultures of the basic principle of western logic of the excluded middle. In western context a creature is either a man or an animal, while in many of the tales presented by Shang, the unnatural lies in creatures being both at the same time. (The werewolf might be a counterexample in western folklore, but as I see it a werewolf is a human that is sometimes transformed into a wolf. There are many stories about them, but as far as I can see, the principle of the excluded other still works, since the creature is completely human when in human

18 Alber (2016, pp. 104-148). 
shape and loses humanity when in animal shape). (3) This uncertainty about certain characters' real essence gives the idea that many stories tell something about human cognition-or about its limited nature. The story of the man who "out of curiosity" looks at his young wife by night and learns that from the waist down she is a skeleton-being the deceased daughter of a prince-tells us something not only about the sexuality in medieval China but also about what was thought of the hierarchy of senses in human cognition in that time and place: through tactile experience the man could not perceive anything strange about the woman, while seeing makes him realise that there is a problem. In many tales, however, seeing is not a real help either. (4) A few stories have an explicitly didactic character, which brings us back to bridging gaps between different literary systems by using western terms. If we use the English category of the tale, we may obscure the didactic character of some pieces that should rather be called fables.

Marshall McLuhan tells the story of how the alphabetic writing formed western civilization, since the "civilized" (McLuhan's quotation marks) man's visual bias "derived from only one source, the phonetic alphabet," and "alphabetic writing at first, and print later, led to the analytic separation of interpersonal relations and inner and outer functions," but also to the ability to "organize all [...] activities on a systemic lineal basis." 19 What if a culture does not have a phonetic alphabet? McLuhan can only see the negative consequences, namely that such a culture necessarily stays tribal, and cannot achieve the "notions of space and time as continuous and homogeneous," although the alphabetisation of their script may help, as the Chinese are presently "determined to" do. ${ }^{20}$ Even if the implied evaluations seem a bit biased, the ideas may show the cultural impact of phonetic/ ideogrammic script. Xiuyan Fu explains the beginnings, or at least the prehistory of Chinese narrative tradition from the Chinese writing, analysing the ornaments of archaic bronze vessels.

Even in this context, in which the ideogram is both ornamentation and text, picture and writing at the same time, Fu makes use of both Chinese and western thinkers (Hobbes, Kant, Barthes) to understand the development of Chinese culture. It is especially illuminating when in the chapter "Fear/Joy" he applies Hobbes' concept of the Leviathan to explain Bronze-Age Chinese mentalities. This may give us the impression that Hobbes managed to describe something really universal about fear as a social factor, and that his thoughts can thus help understand even early China.

When this happens, one may feel satisfied, but as I have tried to show, when the adaptation of a theory of universal claim does not work smoothly, that can be both useful and thought-provoking. On the one hand, when the adaptation of a theory works only partially, with sometimes essential modifications, this may give an impulse to further elaborate the theory; on the other, it highlights the peculiarities or even uniqueness of a different culture. Contemporary narrative theory helps rediscover the Chinese narrative tradition, and this rediscovery contributes both to the versatility of narrative theory and the understanding of Chinese tradition.

\footnotetext{
${ }^{19}$ McLuhan (2011, pp. 108, 152, and 138).

20 Ibid. 48, 152.
} 
Acknowledgements This work was supported by the National Social Science Fund of China (Grant No. 17ZDA281).

\section{References}

Alber, J. (2016). Unnatural narrative: Impossible worlds in fiction and drama. Lincoln: University of Nebraska Press.

Banfield, A. (2005). Skaz. In D. Herman, M. Jahn, \& M.-L. Ryan (Eds.), Routledge encyclopedia of narrative theory (pp. 693-694). London/New York: Routledge.

Bojtár, E. (1992). Szkaz. In I. Szerdahelyi (Ed.), Világirodalmi lexikon (Vol. 14, p. 493). Budapest: Akadémiai.

Conte, G. B. (1999). Latin literature: A history (trans.: Solodow, J. B.). Baltimore, MD: Johns Hopkins University Press.

Eikhenbaum, B. (1962). Illiuziia skaza. Skvoz' literaturu: Voprosy poetiki (pp. 152-156). The Hague: Mouton de Gruyter.

$\mathrm{Fu}, \mathrm{X}$. (1999). Xianqin xushi yanjiu: Guanyu zhongguo xushi chuantong de xingcheng [Studies on the pre-Qin narration: On the formation of Chinese narrative tradition]. Beijing: The Oriental Press.

Gillespie, G. (2016). Zhang Longxi. From comparison to world literature. Recherche Littéraire/Literary Researche, 32, 48-51.

McLuhan, M. (2011). The Gutenberg galaxy (1st ed.). Toronto; Buffalo: University of Toronto Press.

Miner, E. (1990). Comparative poetics. Princeton: Princeton University Press.

Moretti, F. (1999). Atlas of the European novel, 1800-1900. London: Verso.

Moretti, F. (2000). Conjectures on world literature. New Left Review, 1, 54-68.

Nielsen, H. S., Phelan, J., \& Walsh, R. (2015). Ten theses about fictionality. Narrative, 23(1), 61-73.

Prince, G. (1987). A dictionary of narratology. Lincoln: University of Nebraska Press.

Qiao, G. Q. (2015). On the possibilities of developing a Chinese version of narratology. Neohelicon, 42(2), 639-655.

Rajkai, Z. (2003). Történelem és irodalom: képzelet és valóság a kínai elbeszélő irodalomban [History and literature: Imagination and reality in Chinese narrative literature]. In H. Imre \& S. Gergely (Eds.): Kínai nyelv és irodalom. Tanulmányok Csongor Barnabás 80. születésnapjára [Chinese language and literature: A festschrift for Barnabás Csongor] (pp. 178-191). Budapest: Balassi.

Rosenberger, V. (2007). Republican nobiles: Controlling the res publica. In J. Rüpke (Ed.), A companion to Roman religion (pp. 292-303). Oxford: Oxford University Press.

Said, E. (1982). Traveling theory. In The world, the text, and the critic (pp. 226-247). Cambridge: Harvard University Press.

Schleiermacher, F. (1977). Hermeneutik und Kritik (Ed. M. Frank). Frankfurt a. M.: Suhrkamp.

Tian, X. (2010). From the eastern Jin through the early Tang (317-649). In S. Owen (Ed.), The Cambridge history of Chinese literature (pp. 199-285). Cambridge: Cambridge University Press.

Walsh, R. (2007). The rhetoric of fictionality: Narrative theory and the idea of fiction. Columbus: The Ohio State University Press. 